\title{
研究動向
}

\section{ローカルネットワークとして注目される Ethernet}

\author{
東京大学 生産技術研究所石塚満, 安田靖彦 \\ 尾上守夫
}

計算機の進歩と価格の低下は各人に充分な能力を有する計算機を持たせるようになってきた，そ れとともに，その効率的なネットワーク化の要請む高まっている．ランダムアクセス無線パケット 通信の思想を有線に生かし, 簡単なローカルネットワーク手法として注目されるXerox 社の Ethernet について紹介する，また，各種の優先機能の付与を試みているわが国の研究についてむ 触れる.

\section{1. ネットワーク化の要請}

計算機の発展とその価格の低下は, 計算機の使用形態 を大きく変えつつあり, オフィスや研究所, 工場内では 各人が自分の机汇計算機を持つ時代になろうとしてい る. その能力も, ある予想では 5 年後には現在の大型機 (IBM 370/168) に，10 年後には超大型機 (Cray I) に匹 敵するようになるといわれている11.

このような処理機能の分散は，一方では効率的なネッ トワーク化の要請を高めている.ネットワーク化が必要 な目的としては次のような項目が考えられる.

（1）高級資源の共用

高速あるいは高精度のプリンター, 有限要素法や LIPS などに必要な大容量の高速記憶, データベース, 文献検 索などのための大容量ファイル，高速のアレープロセッ サなどは，価格からす使用効率の点からあ各個に保有す ることは困難であって共用したい. 従来の TSS ではこ れらの資源は中央の大型計算機に集中していたが，ロー カルコンピューターネットワークではそれらが分散して いて差し支えない.

（2）ファイルの共用

各自のプログラムやデータを融通し合い，さらに，そ れらを統合化していくチームを組んで大きなソフトウェ アシステムを開発する際など特に必要である.

(3) メールボックス

手紙, 連絡文書, 会合通知などメッセージを単独むし くは複数の宛先に配布する. 相手方は端末の起動時に着 信リストが出され, 必要に応じて内容を読み, 取捨し,

"Ethernet Attracting Attention as A Local Computer Network" py Mitsuru Ishizuka, Yasuhiko Yasuda and Morio Onoe (Institute of Industrial Science, University of Tokyo, Tokyo)
保存する.どのような処理をとったかの記録む管理して くれることが望ましい.

\section{（4）生活情報}

時刻，天気予報，在庫や予算使用状況など，業務を遂 行していくのに必要な情報への迅速なアクセスむできる ととが望ましい.

（5）遠隔保守

分散した多数の個人用計算機の保守はそれ自体大きな 問題である.使用してない時間に診断用プログラムを走 らせて, 故障の発見, 予防保守を行う。またいったん故 障を発見したときは，保守センターから各種のプログラ ムを送って遠隔診断を可能にする。

さて，従来む複数の計算機を接続しネットワークを形 成することは行われており，実際に多くののネットワー クが稼働している．中であ先駆的な役割を果した全米の 大学, 研究機関を結ぶ Arpa ネットが有名である ${ }^{2)}$. し かし，従来のネットワーク技術は必ずしむここで意図し ているような多数の個人用計算機を接続するのに充分で ない，Arpa ネットを例にとると，各ホスト計算機のネ ットワークへの接続のために IMP (Interface Message Processor) と呼ぶ小型計算機が必要であり，プロトコル あかなり複雑である。

最近話題になっているオフィスオートメーションで む, ワークステーションと呼ばれる処理ユニットの効率 的なネットワーク化が重要な目標になっている334). し かし現状では中央計算機に知能的 TSS 端末がついた形 のむのが多く, 数十から数百の処理ユニットを効率的に ネットワーク化する目的には必ずしも適当でない.

てのような状況下で, 簡単な接続手法としてデータハ イウエイやループネットワークなどが提案されてき た5). その中で特に注目されるのが Ethernet である. 
題目にあるように，ここでローカル (コンピューター) ネットワークと“ロー カル”を付しているのはコモンキャリア の提供する回線（日本でいえば電電公社 の回線）を使用しないので，その制約を 受けることがないという意味合いが強 い. 制約がないので広帯域回線を使用す るのむ自由であるし，接続手順であるプ ロトコルもかなり自由に定められるわけ である. 電話の構内交換 (PBX) に対応 していえば, 構内データ交換網というこ 之ができる.だが電話の場合にはどれむ スター状の網形態がとられていたのと異 なり,データ網の場合には多様な形態が 考えられる.

\section{Ethernet とは}

Ethernet の思想の起源である Aloha ネットワークに ついてまず簡単に触れておく。御存知の方む多いと思う が, Aloha ネットはハワイ大学で開発されたランダムア クセス無線パケット通信方式である22.

ハワイ大学ではホノルルの大学本部にある大型コンピ ユーターとオアフ島, カウアイ島, マウイ島に分散する 短期大学, 研究施設の小型コンピューター, ターミナル を図 1 のうに UHF 帯の無線チャンネルで接続して いる. この Aloha ネットではターミナルーホスト間, およびホストーターミナル間を区別し別々の帯域を使用 しているが, 無線によれば元来 $n$ 局間での相互接続が可 能である.

Aloha ネットのターミナル ホストの無線チャンネル を考えると, 各ターミナルは送信すべき情報を 1,000 ビ ット程度のパケットにまとめ, 必要なへッダ情報, 誤り チェック符号を付して任意の時刻に発信する。むしての とき, 他のターミナルからの発信がなければホストは正 しくパケットを受信し， ACK パケットを返送するので, これによってターミナル側では送信が成功したてとを知 る.しかし, ほぼ同時刻他のターミナルからの発信が あると, パケット間での衝突が発生し，ホストでは正し く受信されない，乙のとき各ターミナルでは一定時間待 ち, ACK が返送されなかったら衝突が発生したすのと 判断し, ランダムな遅延時間の後, 同一のパケットの再 送信を行う。このように Aloha ネットでは衝突の発生 により無䭾時間が多くなり, 計算によれば回線のスルー プット (有効使用率) は最大でむ $1 / 2 e$ ，すなわち $18.4 \%$ そしか達しない.

Ethernet はXerox 社によって開発されたローカルコ
図 1 Aloha ネットの接続法

ンピニーターネットワークであり， 前述の Aloha のラ ンダムアクセス無線パケット通信の思想を有線に適用し たものである ${ }^{677)}$. 基本的には無線部分を有線に置き替 えたすのと考えて良いが，有線の特性を生かしたプロ卜 コルの変更により，効率の大幅な改善汃図られている.

システムは図 2 亿例示するように，1本の同軸ケーブ ルを双方向伝送に使用する。各処理ユニットは若干の Ethernet 用インタフェース回路と送受信機を付加して このケーブルに接続され, 放送形式でパケットを送信 し，また自局宛のアドレスが付されたパケットを取り込 む. オフィスや研究所, 工場内に 1 本の同軸ケーブル (伝送速度が低い場合にはペアケーブルでも可能)さえ敷 設すれば，ハードウェア的には若干の回路を付加するこ とによって各パーソナルステーションは容易にネットワ 一クに加入できるととになる.

Ether とは，かつて宇宙にまんべんなく存在するとさ れたあのエーテルのととであり，ケーブルをてのエーテ ルに見立てて命名されている。 てのように Ethernet は ネットワーク自身では何ら制御機能を持たない受動的な 伝送媒体であり，制御は各局に完全に分散されている. したがって信頼性も高い. 各局の立場は対等であり, 接 続された任意の局間での通信が可能である.

有線を使用することによる最大の特長はパケットの衝 突検出が容易なことである. 各局のパケットの送信は図 了に示されるような手順に従う. 送信要求があると,まず Ether 上に他のパケットか存在するか空きかを調べ, 空きでない場合は送信を見合わせる。乙れはCSMA (Carrier Sense Multiple Access) という技術であり, 無線でも可能である.

空きを確認して送信を開始しても，たまたま 2 局以上 


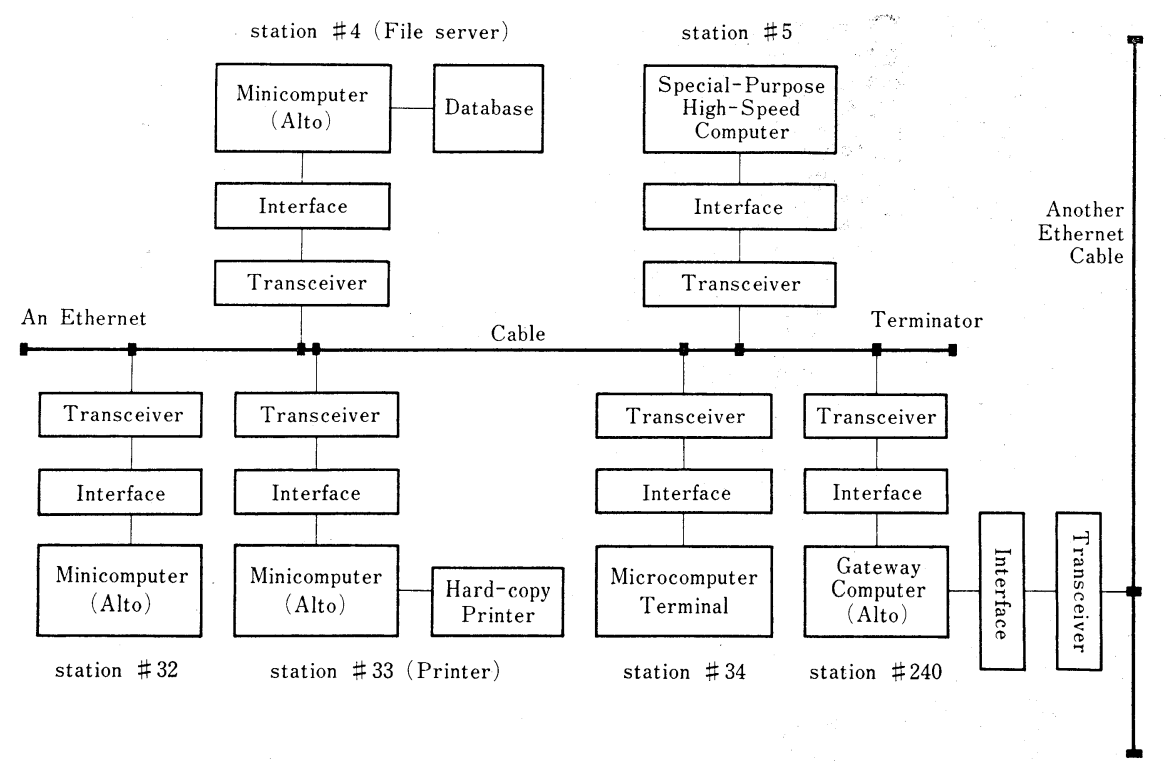

図 2 Ethernet の接続形態の例

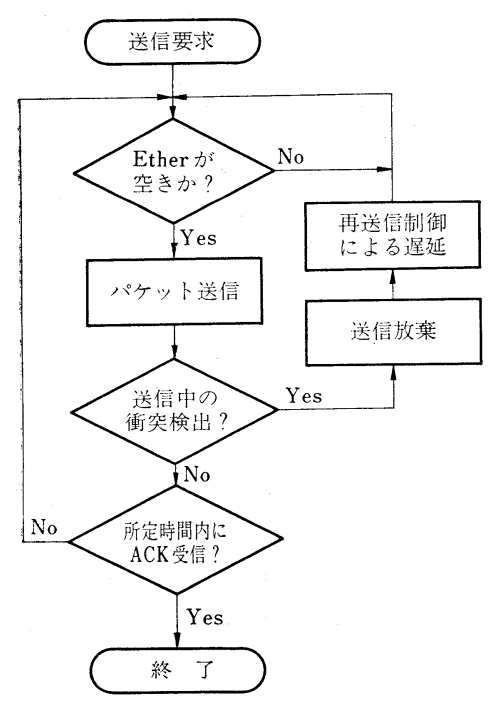

図 3 各局でのパケット送信の制御手順

が同時に送信を開始する場合があり，このときパケット の先頭部で衝突が発生する. Ethernet では各局は送信 中に衝突の検出を続けており，衝突が検出されれば以後 送信を続行しても無䭾なので，ただちに送信を停止す る. この送信中の衝突検出が可能であることが有線の特 長なのである．無線の場合は他局からの信号は空間伝搬 中に大きな減衰を受けるので, 自局の送信波のレベルが 高く他の信号をマスクしてしまうので, 衝突検出が不可 能である.

衝突検出, 送信の放棄後, 2 局が同時に再送信を行う のでは再度衝突を起こすので，ランダムな待ち時間後,
あるいは衝突検出回数に応じて街ち時間を長くとること により, 再衝突の可能性を減少させる. 以上のように, 空きの検出後の送信, 衝突検出時の送信停止によりネッ トワーク使用の無䭾時間はきわめて小となり, 容易に 95 \%以上のスループットが達成される ${ }^{6 / 8)}$. 乙れは無線の Aloha ネットに比較すると驚くべき効率である.

\section{Xerox 社の開発}

EthernetはXerox 社パロアルト研究センター(PARC) で開発され，すでに Xerox 社内では日常的に使用され ている. Ethernet の研究は 1973 年頃より開始された.

パロアルト市はサンフランシスコから南へ約 $80 \mathrm{~km}$, シリコンバレーの北方に位置している. PARCは 3 階建 の建物であり，各階の廓下の天井裏にそれぞれ 1 本の CATV 用低損失用同軸ケーブルが張られている. 長さ はそれぞれ 1 階: 約 $720 \mathrm{~m}, 2$ 階: 約 $530 \mathrm{~m}, 3$ 階: 約 $330 \mathrm{~m}$ である. 研究者の個室が多い2 階は単独で 1 つの Ethernet, 1 階と 3 階のケーブルは BNC コネクタで接 続されて抢り，合わせて1つの Ethernet を形成してい る. 接続されている局数は 2 階が約 $130 ， 1 ， 3$ 階が約 30 である。

Ethernet の考え方は特定の計算機に限られるむので はないが，PARC では写真1に示すようなAlto と呼ば れる個人用計算機をむっぱら使用している.これは64 $256 \mathrm{k}$ の主記憶, $2.5 \mathrm{MB}$ の磁気ディスクをむつ 16 ビッ トの計算機である ${ }^{9)}$ : (608 点 $\times 808$ 行) の縦長の高精細 度ディスプレイをむち，A 4 判の紙面を表現するのに充 分である．また通常の鍵盤の他にマウスと呼ばれるカー 


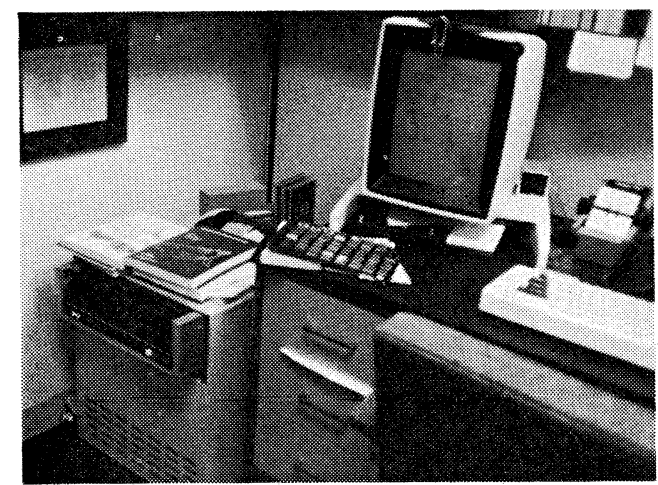

写真 1 Ethernet のパーソナルステーション “Alto” （ディスプレイは高解像度ビットマップ型）

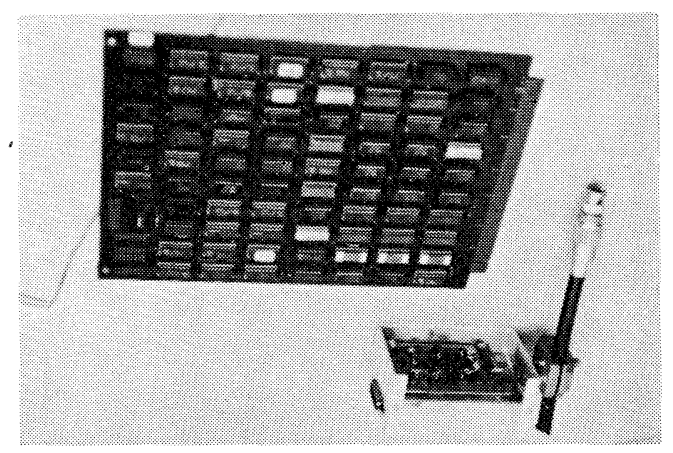

写真 2 Ethernet のケーブルとの接続部とトランシーバー (左上部)および Alto とのインタフェース板

ソル操作器が付いており, 文書やプログラムの作成, CAD などが対話的に便利に行える.

このような高精細度ディスプレイの制御や Ethernet の送信制御などには高速の処理を必要とするため, Alto は 16 種のタスクに CPU 自身が切替えられる一種の I/O 計算機のような構成になっている. 各タスクはマイ クロプログラムで形成され，書替む可能である，標準の Alto には磁気ディスク制御（2 タスク），ディスプレイ およびカーソル制御 ( 4 タスク), Ethernet 制御（1タ スク)があり, ユーザーのためには BCPL, Mesa, Smalltalk などの言語に対するエミュレーターがある99. LIPS ああるが，これは遅いので同じ Ethernet 中の PDP を呼び出して使用しているようである.

写真 2 は Ethernet 用のインタフェース板とケーブル との接続部とトランシーバーである. 各自の計算機に八 ードウェア的にはこれだけ付加すれば，ネットワークに 参入できる.ケーブルとの接続には何むケーブルを切断 する必要はない。CATV 用のタップを流用し，同軸の 外部導体に穴を開け，心線に接続するようにしているだ けのあのであり, Ethernet を拡張性が優れたあのにし ている一要因である.
伝送にはベースバンド信号を使い，速度は $3 \mathrm{Mb} / \mathrm{s}$ で ある. 設計としてはケーブル長 $1 \mathrm{~km}$, その間に最大 256 局を接続できるようになっている. トランシーバーは写 真 2 にあるうにタップに近接して，したがって天井裏 に置かれる。トランシーバーとインタフェース板との間 は 5 対のより線で結ばれる. 前節で述べた Ethernet の 重要な要素である送信中の衝突の検出は, トランシーバ 一内でハードウェア的に実現されている．またケーブル との直流的絶縁むここで行っている.

インタフェース板はコンピューターの種類により多少 設計が異なり, 現在次のようなコンピューター用のイン タフェース板が設計されている (Alto, NOVA, PDP-10 \& 11, SIGMA, HP-21 MX).

各自はプリンターを持たないので, 数カ所に Alto を 介したレーザープリンターが置かれ，ハードコピーが必 要な場合はそこまで取りに行っている. マルチフォント の使用が可能で通常の印刷物と変らない高品質の出力が 得られている.

大容量ファイルも Altoを介して多数の磁気ディスク を接続したファイルサーバーが提供している. PDP-10, NOVA などあ接続されているが，てれはLIPS など Alto より高速の処理や演算を要する仕事に当てられて いる (Alto はハードウェアとしては整数の加減算しか あってない).

Ethernet 間を接続するために, ゲートウェイコンピ ユーターが置かれる. これにも Alto が使われている. Ethernet は PARC だけでなく，すでに Xerox 社内の 各所に建設され，図4のように接続されている.PARC 内の 2 つの Ethernet を結ぶゲートウェイは Porrola と いう愛称で呼ばれ，ATT の回線を通してニューヨーク 州ロチェスターの本社の Ethernet をはじめ, 各所と接 続されている. 加えて Arpa ネットとも接続されてい る.PARC と道を隔てたところに建つ管理棟の Ethernet との間を結ぶゲートウェイには無線設備も設置され，2 マイル程離れた研究施設の Ethernet と無線で接続する ことが試みられている。これは Radionetあるいは PRNet (Packet Radio Net.) と呼ばれている10). ゲー トウェイコンピューターは各局の位置を示すアドレス表 をむち，パケットのルートを決定する役割を果す．

このような異種のネットワーク間の接続にはプロトコ ルの標準化が大切である. Xerox 社では PUP というパ ケットの標準形式を提案している ${ }^{11)}$. 図 5 はその構成と 各ネットワークへの適合を示したあのである.PUP は 標準のプロトコルとして IEEE 規格にする動きむある ようである.

Xerox 社は Ethernet は市販するが, Alto を市販す 


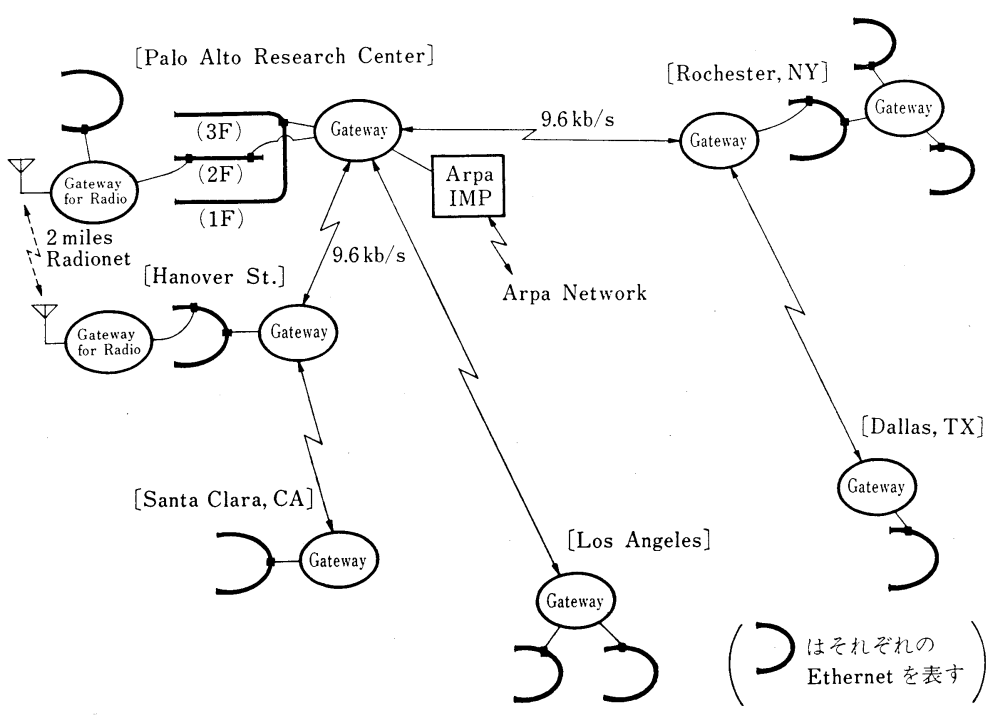

図 4 Xerox 社の Ethernet 間の接続

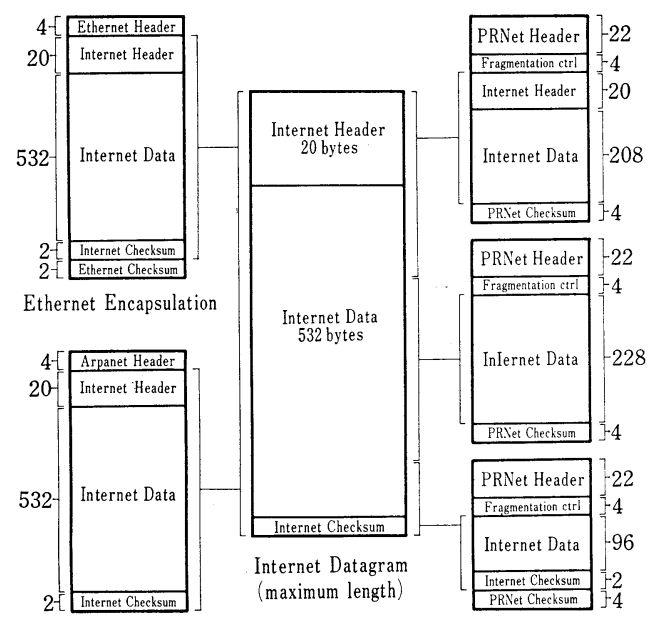

Arpanet Encapsulation

Packet Radio Encapsulation

図 5 異種ネットワーク間接続時のパケットの構成例 (PUP)（数字はバイト数）

る考えはないようである.しかし， Ethernet の普及の ため, MIT, スタンフォード大学, カーネギ・メロン大 学にレーザープリンター付きで寄付している.

\section{4. 優先機能の実現}

ローカルコンピューターネットワークとしてのEthernet の有用性に着目して, わが国でも研究が始められ た. わが国の研究はいずれも Ethernet のパケットに優 先権を与え，ネットワークの応答性の向上や自律的制御 機能を付与することに向けられている.

慶大工学部では ACK 以外のパケットには, 空きの検 出から送信までの間に待ち時間を設けるととにより
$\mathrm{ACK}$ パケットを優先させ, 応答 時間および実効転送効率を向上さ せる Acknowleding Ethernetを 開発している ${ }^{12) ~ 14)}$. 東大生研で は衝突検出が容易なととを積極的 に利用し, 緊急度, 重要度の高い パケットを優先させることによ り, 特に混雑時の効率向上を図る Priority Ethernet を開発してい る15) 18). 早大理工学部では, デ ィジタル内音声のような即時性が 要求される連続的データも混在さ せることを目的として，事前に使 用するタイムスロットの予約をと る Reservation Ethernet を提案 し，試作を行っている ${ }^{19) 20) . ~ た た ゙ ~}$ しこの場合にはランダムアクセス ではなくなることと, Ether ケーブルが完全に受動的な 伝送媒体ではなくなる点で，本来の Ethernet の思想か らはなれている。

以下には東大生研の Priority Ethernet について概要 を紹介する．前述のように Ethernet はネットワーク自 身では何ら制御機能を持たない受動的な伝送媒体であ る.ネットワークが空きになったとき，2局以上でほぼ 同時に送信が開始されると衝突が発生し，いずれの送信 あ停止される．乙の点ですべて平等である. Priority Ethernet ではパケットの緊急度, 重要度に応じて優先 権を与え, 衝突時には優先度の高いパケットに道を譲る ようにしたものである. この優先権の付与により, 各局 がその機能に応じて共用のネットワークを自分のものと して能動的に使用する幅を拡大したあのである.

優先権の付与はパケットの先頭に優先権用のプリアン ブル (priority preamble) のビットパターンを付加し, この期間での衝突検出によっては送信放裹はせず，衝突 の相手局の送信を断念させることによって実現する. 図 6 はパケットの構成を示しており，先頭から 2 番目のプ リアンブルビットはビット同期用, SYNC はヘッダー解 読用の同期パターンである. 優先権用プリアンブルの長 さは優先度に比例して決められる．衝突が発生しても最 む長い優先権用プリアンブルをむつパケットのみが生き 残り，伝送路が確保される.

図 7 はこの様子を示しており, 優先度最低位のレベル 0 は優先権用のプリアンブルなしである.ネットワーク 内の最大伝送遅延を $D_{\max }$, ビットレートを $R, B_{d}=$ $D_{\max } R$ 〔ビット〕とし, インタフェースでの衝突検出か ら送信停止までの処理時間を無視すると,レベル 1 の優 


\begin{tabular}{|c|c|c|c|c|c|c|c|c|}
\hline $\begin{array}{l}\text { Priority } \\
\text { Preamble }\end{array}$ & $\begin{array}{l}\text { Pre- } \\
\text { amble }\end{array}$ & SYNC & $\begin{array}{l}\text { Desti- } \\
\text { nation } \\
\text { Address }\end{array}$ & $\begin{array}{l}\text { Source } \\
\text { Address }\end{array}$ & $\begin{array}{l}\text { Packet } \\
\text { Type }\end{array}$ & $\begin{array}{l}\text { Header } \\
\text { Check }\end{array}$ & Data & $\begin{array}{l}\text { Data } \\
\text { Check }\end{array}$ \\
\hline $16 * 1$ & 8 & 8 & 8 & 8 & 8 & 8 bits & & \\
\hline
\end{tabular}

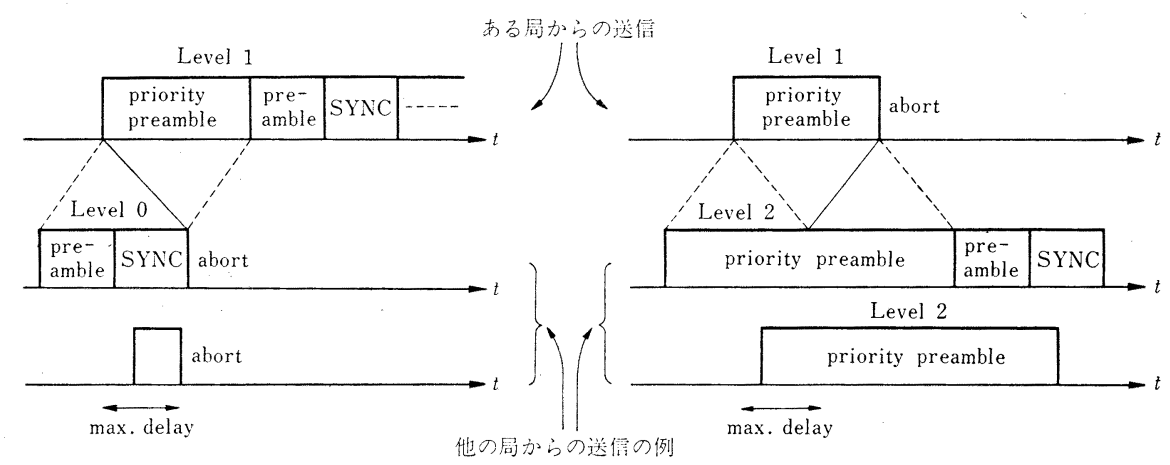

図 7 Priority Ethernet に㧍ける優先機能の実現の様子

表 1 priority level の例

\begin{tabular}{c|l}
\hline \hline priority level & \multicolumn{1}{|c}{ packet type } \\
\hline 6 & $\ldots \ldots \ldots \ldots . . .$. \\
5 & (digital voice) \\
4 & broabcasting \\
3 & ACK or NAK from high-traffic interface \\
2 & ACK, NAK \\
1 & data from high-traffic interface \\
0 & data \\
\hline
\end{tabular}

先権用プリアンブル長は最低 $2 B_{d}$ ビット, レベル 2 は $4 B_{d}$ ビット……なる. ケーブル長 $1 \mathrm{~km}$ のとき $D_{\max }$ $\simeq 5 \mu \mathrm{s}$ であり, $R=1 \mathrm{Mb} / \mathrm{s}$ のとき $2 B_{d}=10$ ビットとな る.ただし，レベル 2 以上では最初の $2 B_{d}$ ビット間で 衝突が生じなかったら, 自動的に優先権用プリアンブル を打ち切るようにすれば，不必要に長くなることを防止 できる。

表 1 はパケットの種類に応じた優先度の割り振りの例 を示している. ACK パケットを優先することにより， パケット正常受信の確認が返送されるのを待つ時間を短 縮できる. 優先機能を活用して, 即時性が要求されるデ イジタル音声パケットも通せるのではないかと現在検討 中である．優先機能がネットワーク全体に能動的に作用 することを利用して，自局内のバッファの飽和を予知し 優先度を上昇させる, さらに進んで他局のパケットの存 在中にむ割り込むととなどあ可能となるが，この場合に はデッドロック状態の回避を図る必要がある.

Priority Ethernet は現在，2局と擬似好害局が完成 しており，良好な動作が確認されている.

\section{5.むす び}

多数の個人用計算機を経済的にネットワーク化する方 法として Ethernet を紹介した. Ethernet のローカル コンピューターネットワークとしての特長をあげると次 のようになる.

（1） ネットワーク形態が 1 本のケーブルを媒体とす るむので，簡単に設置できる.

（2）ランダムアクセスが可能であり，接続のための 伝送制御手順の思想む簡素である.

（3）ネットワーク自体は完全に受動的であり, 制御 は各局に分散されているので，信頼性が高い.

（4）新規の参入が容易であり，拡張性が優れてい る.

今後の課題としては, 光ファイバーケーブルを使う場 合によ゙のようにするが21), 広域網（日本では電電公社の 新データ網）との有効な接続をいかにして図るかなどが あろう. 光ファイバーの場合には分岐に伴う減衰が大き な問題となっている.

本稿を草する機会を与えられた高木編集幹事, Ethernet の見学を許され貴重な御意見をいただいた PARC の D. Boggs 氏，N. Suzuki 氏に厚く感謝する．また東 大生研に括ける Priority Ethernet の研究は大学院生の 飯田一郎氏に負うところが多いことを記し，感謝する次 第である.

(昭和 55 年 2 月 18 日受付)

\section{〔参考文 献〕}

1) P. Isaacson: Personal Computing: A Little Past anb A Lot of Future, 第1 回マイクロコンピュータ 応用国際コンファレンス (1978) 53-62 
2) N. Abramson and F.F. Kuo ed.: Computer-Communication Network, Prentice-Hall (1973); 猪瀬監 訳, コンピュータネットワーク, 産業図書 (1975)

3) N. Mokhoff: Office Automation: A Challenge, IEEE Spectrum, 16, 10 (1979) 66-69

4）相磯, 坂村: オフィス・オートメーションの幕明け, bit, 12, 1 (1980) 4-10

5）土谷：ローカルコンピュータネットワーク,信学誌，62, 11 (1979) 1310-1316

6) R.M. Metcalfe and D. Boggs: Ethernest: Distributed Packet Switching for Local Computer Networks, Comm. ACM, 19, 7 (1976) 395-404

7）安田：情報の分配・収集通信システムについて，機械学 会, 異常検知・故障予測研究分科会資料 (1978.1)

8) J.F. Shoch and J.A. Hupp: Performance of an Ethernet Local Network-A Preliminary Report, Local Area Comm. Net. Symp., Boston, May (1979)

9) C.P. Thacker, E.M. McCreight, B.W. Lampson, R.F. Sproull and D.R. Boggs: Alto: A Personal Computer, Xerox PARC Report, CS-79-11, Aug. (1979)

10) J. Shoch and L. Stewart: Internetwork Experiments with the Bay Area Packet Radio Network, Xerox PARC Report, SSL-79-4, Feb. (1979)

11) D. Boggs, J. Shoch. E. Taft and R. Metcalfe: Pup: An Internetwork Architecture, IEEE Trans., COM-
28, 1 (1980)

12) M. Tokoro and K. Tamaru: Acknowleding Ethernet, COMPCON 77 (1977)

13）田丸，所：Acknowleding Ethernet System の設計, 信学技報, EC 77-69 (1978)

14) 松本, 前田, 䧃田, 中川：BEST-I (Buffered Ethernet System model-I) 信学技報, EC 79-10 (1979)

15）尾上, 安田, 石塚：優先権付ランダム・アクセス有線パ ケット通信方式-Priority Ethernet, 情処全大, 3A-1 (1978)

16）尾上, 安田, 石塚, 飯田：Ethernet のスループットに 関する検討, 信学総合全大, 1443 (1979)

17）尾上, 安田, 石塚, 飯田: Priority 機能をむつ Ethernet の応答特性, 情処全大, 4G-2 (1979)

18）飯田, 石塚, 安田, 尾上: Priority Ethernet の試作, 信学総合全大, 1382 (1980)

19）富永，姜: Reservation Ether Network の提案とその 概要，信学通信部門全大，130（1978）（関連論文が同 131〜137 に発表されている)

20）本多, 平野, 上野, 斉藤, 富永, 平出: Reservation Ether Network に拉ける電話端末を考慮したハードウ エア構成, 情処全大, 4G-3 (1979)

21) E. G. Rawson and R.M. Metcalfe: Fibernet: Multimode Optical Fibers for Local Computer Network, IEEE Trans., COM-26, 7 (1978) 983-990

\section{テレビジョン学会誌 6 月号予定目次}

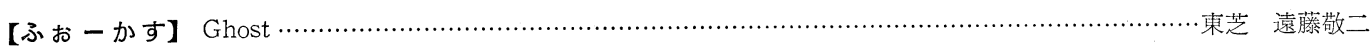

【技 術 解 説】画像計測におけるディジタル技術の応用……………………………………....浜松テレビ 倉沢一男

【研 究 動 向】テレビジョン方式回路の研究動向

電通大 長谷川伸・松下電器 木谷晃夫 ・東芝 竹村裕夫 $・ N H K$ 村上敬之助

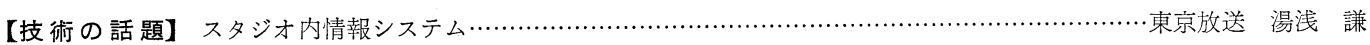
無線制御によるスタジオ照明…………………..............................東芝電材 岡田和己・長崎文彦

民生用音声合成・認識装置……………………………………………………芝 新田恒雄 「シルクロード」番組制作——ネガ送像，ビデオ編集，ステレオ音声制作技術——

NHK 小川 武・荻原清邦・松原勝正・小幡伊和男

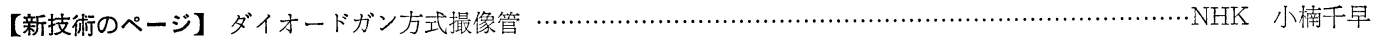

【論 文・資 料】静止画 NTSC 信号のフィールド間補間サブナイキスト標本化方式…………日立 阿知葉征彦・石倉和夫 隣接した中波ラジオ送信空中線の放射特性に関する理論解析

NHK 上中田勝明・青柳公男・斉藤 譲

【これすほんでんす】U-M V-U 方式による高画質8 波伝送テレビ共聴システムの開発 三上技術士事務所 三上貞夫

【講

座】半導体応用回路：電源回路.

松下電子 藪 能昌 $\cdot$ 前田幹夫

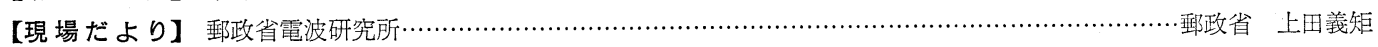

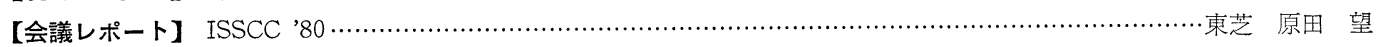

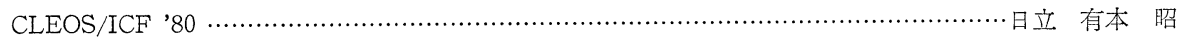

第 58 回 NAB 大会レポート………………………………………... フジテレビ 清水芳之 